\title{
Characterization of arabinoxylan degrading enzymes during wheat malting
}

\author{
Bao Chu ${ }^{1 \#}$, Yanan Chai ${ }^{2 \#}$, Yuhong Jin ${ }^{1 *}$, Zhaoan $\mathrm{Zhang}^{3}$, Xiao Yang ${ }^{1}$, and Junhan Liu ${ }^{1}$ \\ ${ }^{1}$ College of Food Science and Engineering, Shandong Agricultural University, No. 61 Daizong Street, Tai'an, 271018, Shandong \\ Province, PR China. \\ ${ }^{2}$ Department of Modern Services, Rizhao Technician College, No. 2 Linyi North Road, Rizhao, 276800, Shandong Province, PR China. \\ ${ }^{3}$ Tai'an Tai shan Beer Co., No. 99 Keji North Street, Tai'an, 271000, Shandong Province, PR China.
}

\begin{abstract}
In this paper the arabinoxylanase activities and the content of water-extractable arabinoxylans (WEAXs) including their degradation products in wheat Yannong 24 during the malting process were studied. The results showed that the endo- $\beta-1,4$-xylanase activity had a large increase during the steeping process, endo- $\beta$-1,4-xylanase and $\alpha$-L-arabinofuranosidase achieved the highest activity on day 4 of germination. During malt kilning, endo- $\beta-1,4$-xylanase and $\alpha$-L- arabinofuranosidase were not heat stable, and the activity decline rate were $65.88 \%$ and $69.58 \%$; whereas malt $\beta$-D-xylosidase was resistant to heat and it's activity decline rate was only $18.74 \%$. It is during steeping and the first day of germination that the content of WEAXs and it's degradation products (WEAXs+DP) dramatically increased, and this corresponded to the greater improvement of endo- $\beta-1,4$-xylanase activity in the same phase. The WEAXs+DP content has a very significant positive correlation with the endo- $\beta-1,4$-xylanase activity $(0.892$, $\mathrm{p}<0.01)$. It can be indicated that endo- $\beta-1,4$-xylanase is the main degrading enzyme in the degradation of WUAXs and the increase of the WEAXs content during steeping and the first day of wheat germination.
\end{abstract}

\section{Introduction}

Wheat and wheat malt are known to be high quality raw materials in the beer brewing process ${ }^{[1]}$, and with the rapid development of the brewing industry in China, wheat malt is now widely used in the beer brewing industry.

Arabinoxylans (AXs) are the primary non-starch polysaccharides found in the cell walls of wheat cells ${ }^{[2-4]}$, with molecular weights ranging widely between 10 and $10,000 \mathrm{kDa}$. AX forms a relatively viscous solution, with both water-unextractable (WUAX) and waterextractable (WEAX) forms present. The basic structure of $\mathrm{AX}$ is that of $\alpha$-L-arabinofuranosyl residues linked by $\mathrm{C}(\mathrm{O})-2, \mathrm{C}(\mathrm{O})-3$ or $\mathrm{C}(\mathrm{O})-2,3$ glycosidic bonds to a linear backbone composed of $\beta-(1,4)$-D-xylopyranosyl units, with mono- or di-arabinose substitutions found along the xylose backbone ${ }^{[5]}$.

There are three categories of enzymes that play a primary role in the degradation of AXs, namely, endo- $\beta$ 1,4-xylanases (EC 3.2.1.8), $\beta$-D-xylosidases (EC 3.3.1.37) and $\alpha$-L-arabinofuranosidase (EC 3.2.1.55) ${ }^{[6-7]}$. Random enzymatic cleavage along the xylose backbone by endo- $\beta-1,4-x y l a n a s e$ results in the release of xylooligosaccharide products, allowing exo- $\beta$-D-xylosidase to remove xylose units successively from non-reducing ends of the xylo-oligosaccharides ${ }^{[8]}$. The existence of side-chain substituents may have an inhibitory effect on the activity of endo- $\beta$-1,4-xylanase and $\beta$-D-xylosidase; thus, $\alpha$-L-arabinofuranosidase also plays an essential role in xylan degradation by mediating hydrolysis of the glycosidic bonds between the xylose backbone and sidechain substituents.

The overall AXs content in wheat and barley are similar; however, the WEAXs content is higher in wheat ${ }^{[9]}$, resulting in higher WEAXs in malt. The endogenous AXs degrading enzymes found in wheat are active during the mashing and malting process, and can convert WUAXs into WEAXs macromolecules ${ }^{[10-11]}$. Peng and $\mathrm{Jin}^{[12]}$ have also isolated and characterized an endo-1,4- $\beta$-xylanase from wheat malt.

A significant number of research reports have been published regarding AX degrading enzymes found in barley ${ }^{[13]}$ and barley malt ${ }^{[14-15]}$, but relatively few studies have been reported for the wheat malting process. Wheat malt is a widely used raw material for beer production; however, a large amount of WEAXs remains during brewing, and is found in the final product ${ }^{16]}$. Some WEAXs with large molecular weight that can bring problems, including the wort leaching rate, high viscosity ${ }^{[17]}$, filtration difficulties ${ }^{[18]}$ and even lead to the point of causing beer turbidity and other issues. The present study determined the concentration of the WEAXs, as well as the activity changes of the three primary AXs degrading enzymes. The analysis of the relationship between the enzymatic activities and the characteristics of AXs provides a theoretical foundation for future improvements of the wheat malting process.

\footnotetext{
${ }^{*}$ Corresponding author: yuhongjin79@sdau.edu.cn

${ }^{\#}$ The first two authors contributed equally to this work.
} 


\section{Materials and Methods}

\subsection{Experimental materials and reagents}

\subsubsection{Experimental materials}

The wheat variety Yannong 24, which was obtained from Shandong Academy of Agricultural Sciences (Yantai, Shandong) was used as the raw material and malted according to the method described by Jin ${ }^{[19]}$. The sampling started at the end of steeping process and carried out once every 24 hours. Considering the effect of drying process on enzyme activity, the sample was divided into two portions. One portion of the green malt was used for enzymatic activity assays of endo- $\beta-1,4-$ xylanase, $\beta$-D-xylosidase and $\alpha$-L-arabinofuranosidase (labeled as E-0, E-1, ... E-5 according to the number of days after germination) whereas the other portion of the green malt was subjected to a normal drying process in order to obtain the dried malt (labeled as $\mathrm{M}-0, \mathrm{M}-1, \ldots$ M-5 according to the number of days after germination). The quality of wheat malt was analyzed according to QB/T 1686-2008 Barley malt. Basic indicators of the wheat malt obtained were shown in Table 1.

\subsubsection{Reagents}

The p-nitrophenyl- $\alpha$-L-arabinofuranoside, p-nitrophenyl$\beta$-D-xylopyranoside and RBB-xylan were purchased from SIGMA Company.

\subsubsection{Instruments}

EBC-LF standard malt mill was purchased from Beijing Dezhijie Co., Ltd (Beijing, China). LRH-250-A biochemical incubator was purchased from Shaoguan Thaihung Medical Instrument Co., Ltd. IKAMAG electromagnetic stirrer was purchased from RET-GS JANKE \& KUNKEL GAME \& CO.KG. LC-2010AT high-performance liquid chromatography (HPLC) system was purchased from Shimadzu Corporation (City, Japan).

\subsection{Enzymatic activity assays}

\subsubsection{Extraction of crude enzymes}

The finished product of malt was ground by using a $0.2-$ $\mathrm{mm}$ sieve. A total of $20 \mathrm{~g}$ malt powder was added to 70
$\mathrm{mL}$ of $0.05 \mathrm{M}$ phosphate buffer ( $\mathrm{pH} 7.0)$. After stirring extraction in an ice bath for 30 minutes, the solution was topped up to $100 \mathrm{~mL}$. The solution was centrifuged at $5000 \mathrm{rpm}$ at $4{ }^{\circ} \mathrm{C}$ for 15 minutes. The supernatant was harvested and filtered through a $0.45-\mu \mathrm{m}$ membrane filter to obtain the crude enzyme solution. The crude enzyme solution was then stored in a $4{ }^{\circ} \mathrm{C}$ refrigerator.

\subsubsection{Endo- $\beta-1,4-x y l a n a s e$ activity assay}

The endo- $\beta-1,4$-xylanase activity assay was performed according to the method of $\mathrm{Guo}^{[20]}$.

\subsection{3. $\alpha$-L-arabinofuranosidase activity assay}

A total of $0.5 \mathrm{~mL}$ crude enzyme solution was added to $2.5 \mathrm{~mL}$ of $0.05 \mathrm{M}$ acetic acid-sodium acetate buffer solution ( $\mathrm{pH} 4.5)$ and equilibrated in a circulating water bath at $45^{\circ} \mathrm{C}$ for 10 minutes, followed by the addition of $1 \mathrm{~mL}$ substrate (1 $\mathrm{mmol} / \mathrm{L} \quad \mathrm{p}$-nitrophenyl- $\alpha$-Larabinofuranoside). The blank control was prepared via the addition of $1 \mathrm{~mL}$ of $2 \%$ Tris-base solution to inactivate the enzymatic activity before the addition of substrate. After 10 minutes of reaction, $1 \mathrm{~mL}$ of $2 \%$ Trisbase was used to terminate the reaction. Then, the solution was centrifuged at $10000 \mathrm{r} / \mathrm{min}$ for 5 minutes and the supernatant was harvested for the measurement of absorbance at $410 \mathrm{~nm}$.

The enzyme unit of $\alpha$-L-arabinofuranosidase was represented as 0.01 change of the absorbance at $410 \mathrm{~nm}$ per hour in each $g$ of the bone-dry raw material at $45^{\circ} \mathrm{C}$ relative to the absorbance value of control.

\subsection{4. $\beta-D$-xylosidase activity assay}

The enzymatic activity assay was performed by using the method described in section 2.2.3 with slight modifications. A total of $0.2 \mathrm{~mL}$ crude enzyme solution was added to $2.8 \mathrm{~mL}$ of $0.05 \mathrm{M} \mathrm{NaAC-HAC}$ buffer solution ( $\mathrm{pH} 4.5$ ) and equilibrated in a circulating water bath at $70{ }^{\circ} \mathrm{C}$ for 10 minutes in a circulating water bath, followed by the addition of $1 \mathrm{~mL}$ substrate solution (1 $\mathrm{mmol} / \mathrm{L}$ p-nitrophenyl- $\beta$-D- xylopyranoside).

The enzyme unit of $\beta$-D-xylosidase was represented as 0.01 change of the absorbance at $410 \mathrm{~nm}$ per hour in each $g$ of bone-dry raw material at $70{ }^{\circ} \mathrm{C}$ relative to the absorbance value of control.

Table 1 Characteristics of the wheat malts during the malting process

\begin{tabular}{ccccccc}
\hline Wheat malts & M-O & M-1 & M-2 & M-3 & M-4 & M-5 \\
\hline \multicolumn{7}{c}{} \\
\hline Water content (\%) & $5.5 \pm 0.0 \mathrm{~b}$ & $5.8 \pm 0.0 \mathrm{a}$ & $5.1 \pm 0.0 \mathrm{c}$ & $5.0 \pm 0.0 \mathrm{c}$ & $4.9 \pm 0.0 \mathrm{~d}$ & $4.3 \pm 0.0 \mathrm{e}$ \\
Chromaticity (EBC) & $3.33 \pm 0.00 \mathrm{f}$ & $4.47 \pm 0.00 \mathrm{~d}$ & $4.09 \pm 0.00 \mathrm{e}$ & $4.71 \pm 0.00 \mathrm{c}$ & $5.16 \pm 0.00 \mathrm{~b}$ & $6.17 \pm 0.00 \mathrm{a}$ \\
$\alpha$-amino nitrogen (mg/100g) & $51.4 \pm 0.6 \mathrm{c}$ & $84.1 \pm 0.0 \mathrm{~b}$ & $120.8 \pm 0.6 \mathrm{a}$ & $124.3 \pm 0.3 \mathrm{a}$ & $120.2 \pm 0.6 \mathrm{a}$ & $120.3 \pm 0.6 \mathrm{a}$ \\
Extract (\%) & $72.8 \pm 0.0 \mathrm{f}$ & $79.6 \pm 0.0 \mathrm{e}$ & $81.7 \pm 0.0 \mathrm{c}$ & $82.2 \pm 0.0 \mathrm{a}$ & $81.9 \pm 0.0 \mathrm{~b}$ & $81.3 \pm 0.0 \mathrm{~d}$ \\
\hline
\end{tabular}




\begin{tabular}{ccccccc}
\hline Kolbach Index (\%) & $17.6 \pm 0.1 \mathrm{e}$ & $25.4 \pm 0.0 \mathrm{~d}$ & $33.7 \pm 0.6 \mathrm{c}$ & $35.0 \pm 0.2 \mathrm{~b}$ & $35.8 \pm+0.3 \mathrm{ab}$ & $36.8 \pm 0.2 \mathrm{a}$ \\
Viscocity $(\mathrm{mPa} \cdot \mathrm{s})$ & $2.23 \pm 0.00 \mathrm{a}$ & $2.13 \pm 0.00 \mathrm{~b}$ & $1.67 \pm 0.00 \mathrm{c}$ & $1.61 \pm 0.00 \mathrm{~d}$ & $1.52 \pm 0.00 \mathrm{f}$ & $1.56 \pm 0.00 \mathrm{e}$ \\
Diastatic power $(\mathrm{WK})$ & $179 \pm 0 \mathrm{f}$ & $220 \pm 1 \mathrm{e}$ & $304 \pm 4 \mathrm{~d}$ & $323 \pm 0 \mathrm{c}$ & $366 \pm 0 \mathrm{a}$ & $332 \pm 1 \mathrm{~b}$ \\
Total nitrogen $(\%)$ & $2.3 \pm 0.0 \mathrm{a}$ & $2.3 \pm 0.0 \mathrm{a}$ & $2.3 \pm 0.0 \mathrm{a}$ & $2.3 \pm 0.0 \mathrm{a}$ & $2.3 \pm 0.0 \mathrm{a}$ & $2.4 \pm 0.0 \mathrm{a}$ \\
\hline
\end{tabular}

Note: Different alphabets in each row indicate a significant difference $(p<0.05)$. M- $0, \mathrm{M}-1, \ldots \mathrm{M}-5$ refer to the dried malt at the end of steeping process, the first day, the second day ...... the fifth day of germination, respectively, and the same hereinafter.

\subsection{Determination of the content of WEAX and its degradation products}

The phloroglucinol-based colorimetry was carried out by using xylose as a standard. A standard curve was constructed by plotting the xylose concentrations $(\mathrm{mg})$ on the $\mathrm{x}$-axis and the absorbance at 552-nm on the y-axis. The data were fitted into the equation $y=2.6354 x+0.0134$ with $r^{2}$ of 0.9981 .

The finished product of the malt was ground by using a $0.2-\mathrm{mm}$ sieve. A total of $20 \mathrm{~g}$ malt powder was added to $100 \mathrm{~mL}$ water and after the stirring extraction in an ice bath for 60 minutes, the solution was centrifuged at 5000 $\mathrm{r} / \mathrm{min}$ for 15 minutes. The supernatant was harvested for measurement.

During the measurement, the sample solution was appropriately diluted by adding $1 \mathrm{~mL}$ diluent to $5 \mathrm{~mL}$ phloroglucinol-glacial acetic acid reaction solution. After incubation in a boiling water bath for 25 minutes, the reaction was terminated in an ice bath, followed by the A552 measurement. The content of WEAX and its degradation products $($ WEAXs + DP) in the sample was calculated based on the standard curve.

\subsection{Data processing}

The data were averages of three replicates. Correlation and differential analyses were carried out by using the SPSS 17.0 and DPS 9.50 analysis software. Correlation coefficients with a very significant correlation at the 0.01 level in the correlation analysis were indicated by "**”, whereas "*" indicates a significant correlation at the 0.05 level. Different lower case alphabets in the differential analysis indicate a significant difference at the 0.05 level.

\section{Results and Discussion}

\subsection{Arabinoxylanase activities in wheat during the malting process}

Activity changes of endo- $\beta-1,4$-xylanase, $\beta$-Dxylosidases and $\alpha$-L-arabinofuranosidase in the malting process were shown in Figure 1. It could be seen from Figure 1 that the enzymatic activity of endo- $\beta-1,4-$ xylanase was low in the raw wheat at $1.27 \mathrm{u}$. At the end of the steeping process, the enzymatic activity of endo- $\beta$ 1,4-xylanase increased significantly up to $7.71 \mathrm{u}$, but slightly decreased on the first and second day of germination to $6.18 \mathrm{u}$ and $5.74 \mathrm{u}$, respectively. The enzymatic activity gradually increased on the third and fourth day of germination to $8.21 \mathrm{u}$ and $10.10 \mathrm{u}$, respectively, where it reached a plateau on the fourth day. The enzymatic activity slightly decreased on the fifth day of germination, but it was not significantly different from that on the fourth day, indicating that the enzymatic activity of endo- $\beta$-1,4-xylanase was stable after 4 days of germination. The reason for the activity declined of endo- $\beta-1,4-x y l a n a s e$ at the first and second day of germination might be that extraction of enzyme contained some WEAXs derived from wheat malt. And in the process of enzyme activity determination, the WEAXs in the enzyme extraction occupied some endo- $\beta$ -1,4-xylanase, so that the enzyme activity became smaller. While in late germination the WEAXs molecules in the wheat malt became smaller, no longer suitable as substrates for endo- $\beta-1,4$-xylanase, no longer take up endo- $\beta-1,4$-xylanase. So that the activity of endo- $\beta$-1,4-xylanase rised.

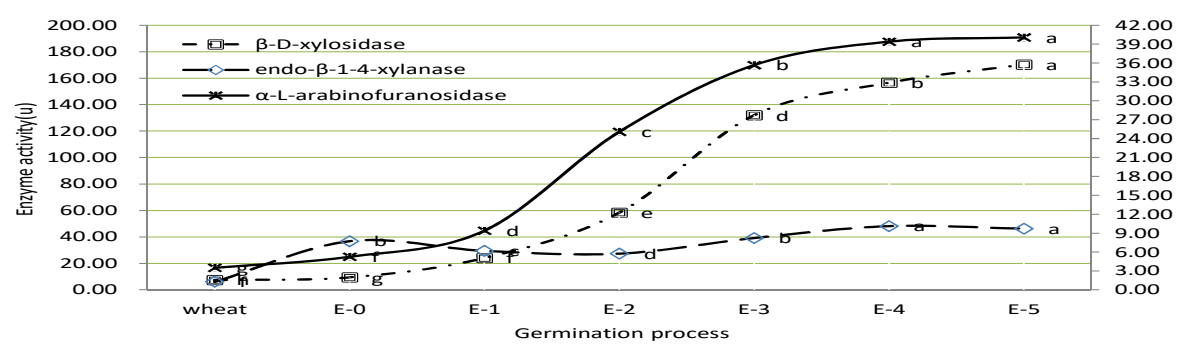

Fig. 1 Enzyme activity change of xylanase in the process of malting. E-1, .. E-5 refer to the green malt of the first day, the second day ...... the fifth day of germination, respectively, and the same hereinafter. Y-axis on the left is for the activity of $\beta$-D-xylosidase. $\mathrm{Y}$-axis on the right is for the activity of endo- $\beta-1-4$-xylanas and $\alpha$-L-arabinofuranosidas

Changes in $\beta$-D-xylosidase and $\alpha$-Larabinofuranosidase activities were basically consistent with one another during the malting process. Their enzymatic activities were the lowest in the raw wheat, slightly increased at the end of the steeping process, and then significantly increased during the germination in a time-dependent manner. The $\alpha$-L-arabinofuranosidase activity peaked on the fourth day of germination and did 
not change significantly on the fifth day relative to the fourth day. The $\beta$-D-xylosidase activity peaked on the fifth day of germination. However, the $\beta$-D-xylosidase activity was greatly higher than the $\alpha$-Larabinofuranosidase activity (Table2). The $\beta$-Dxylosidase activities in the raw wheat, green malt, and final product of the malt $(7.36 \mathrm{u}, 170.31 \mathrm{u}$ and $138.39 \mathrm{u}$, respectively) were 2,4 , and 11 times greater than the $\alpha$ L-arabinofuranosidase activities $(3.50 \mathrm{u}, 40.07 \mathrm{u}$ and $12.19 \mathrm{u}$, respectively).

Table 2 Comparison of the xylanase activity in wheat, green wheat malt and dry wheat malt

\begin{tabular}{lcccc}
\hline \multicolumn{1}{c}{ Enzyme } & & Enzyme activity $(\mathrm{u})$ & \multicolumn{2}{c}{$\begin{array}{c}\text { Decline rate in } \\
\text { the drying } \\
\text { process }\end{array}$} \\
\cline { 2 - 5 }$(\%)$
\end{tabular}

Note:The results suggested the best germination time was between four to five days regarding the enzymatic activities of xylanases in the wheat malt.

\subsection{Changes in the content WEAXs+DP during the malting process}

Changes in content of WEAXs+DP during wheat malting were shown in Table 3 . Table 3 showed that the WEAXs+DP content was $5.25 \mathrm{mg} / \mathrm{g}$ in the raw wheat, $6.77 \mathrm{mg} / \mathrm{g}$ at the end of steeping process, $12.09 \mathrm{mg} / \mathrm{g}$ on the first day of germination, and $12.94 \mathrm{mg} / \mathrm{g}$ on the second day of germination, then $13.23 \mathrm{mg} / \mathrm{g}, 13.72 \mathrm{mg} / \mathrm{g}$ and $13.80 \mathrm{mg} / \mathrm{g}$ on the third, fourth and fifth day. The increment of the WEAXs content was due to the degradation of arabinoxylan by the endogenous xylanase that leads to the conversion of WUAXs into WEAXs. In the malting process of wheat malt, the WEAXs+DP content mainly increased during the steeping process and the first day of germination. indicating that the conversion of WUAXs into WEAXs in wheat was more intense during the steeping process and the first day of germination. The WEAXs+DP content in the malt changed slightly after the second day of germination. indicating that the conversion of WUAXs into WEAXs in wheat was slower. But may be the conversion that WEAXs from large molecules to small molecules were more intense, this speculation needed to be confirmed by further study.

Table 3 Changes of the content of water-extractable arabinoxylan during the malting process

\begin{tabular}{ccc}
\hline Germination & $\begin{array}{c}\text { WEAXs+DP } \\
\text { content }(\mathrm{mg} / \mathrm{g})\end{array}$ & $\begin{array}{c}\text { Increasing rate } \\
\text { of WEAXs+DP } \\
\text { content }(\%)\end{array}$ \\
\hline wheat & $5.25 \pm 0.05 \mathrm{f}$ & 0.00 \\
M-0 & $6.77 \pm 0.10 \mathrm{e}$ & 28.88 \\
M-1 & $12.09 \pm 0.09 \mathrm{~d}$ & 130.29 \\
M-2 & $12.94 \pm 0.18 \mathrm{c}$ & 146.17 \\
M-3 & $13.23 \pm 0.08 \mathrm{~b}$ & 151.94 \\
M-4 & $13.72 \pm 0.07 \mathrm{a}$ & 161.33 \\
M-5 & $13.80 \pm 0.15 \mathrm{a}$ & 162.80 \\
\hline
\end{tabular}

As can be seen from Table 2, the enzymatic activities of the xylanases in the malt decreased before and after the drying process, whereas the activities of endo- $\beta-1,4-$ xylanase, $\alpha$-L-arabinofuranosidase and $\beta$-D-xylosidase decreased by $65.88 \%, 69.58 \%$, and $18.74 \%$, respectively The results showed that endo- $\beta-1,4$-xylanase and $\alpha$-Larabinofuranosidase in the wheat malt were not heatresistant, whereas $\beta$-D-xylosidase had a higher heat resistance.

Note:Increasing rate of WEAX $s+D P$ content $(\%)=($ WEAXs + DP content in malt - WEAXs + DP content in wheat)/ WEAXs + DP content in wheat $\times 100$

\subsection{Correlation between the arabinoxylanase activities and the WEAXs+DP content}

The correlation between the activities of the three arabinoxylanases and the WEAXs+DP content was presented in Table 4 . The WEAXs+DP content has a very significant positive correlation with the endo- $\beta-1,4-$ xylanase activity $(0.892, \mathrm{p}<0.01)$. However, it does not have a significant correlation with the activities of $\alpha$-Larabinofuranosidase and $\beta$-D-xylosidase, indicating that endo- $\beta-1,4$-xylanase is the main degrading enzyme in the degradation of AXs and the increase of the WEAXs content in the malting process. There was a significant positive correlation between the activity of endo- $\beta-1,4-$ xylanase and $\beta$-D-xylosidase $(0.765, \mathrm{p}<0.05)$ and a very significant positive correlation between the activity of $\alpha$ L-arabinofuranosidase and $\beta$-D-xylosidase (0.976, $\mathrm{p}<0.01$ ), indicating that there is a certain synergy between these two types of enzymes.

Table 4 Correlation between the activities of the arabinoxylan degrading enzymes and the content of WEAXs

\begin{tabular}{ccccc}
\hline & $\begin{array}{c}\text { WEA } \\
\text { Xs }\end{array}$ & $\begin{array}{c}\text { endo- } \\
\beta-1-4- \\
\text { xylan } \\
\text { ase }\end{array}$ & $\begin{array}{c}\alpha-\mathrm{L}- \\
\text { arabinofurano } \\
\text { sidase }\end{array}$ & $\begin{array}{c}\beta \text {-D- } \\
\text { xylosid } \\
\text { ase }\end{array}$ \\
\hline $\begin{array}{c}\text { WEAXs } \\
\text { endo- } \beta-1-4- \\
\text { xylanase } \\
\alpha-L-\end{array}$ & $\begin{array}{c}0.892 \\
* *\end{array}$ & 1 & & \\
$\begin{array}{c}\text { arabinofurano } \\
\text { sidase } \\
\beta-D-\end{array}$ & 0.711 & 0.747 & & \\
xylosidase & 0.650 & $*$ & & \\
\hline
\end{tabular}




\section{Conclusion}

The enzymatic activity of endo- $\beta-1,4-x y l a n a s e s$ increased at the highest magnitude during the steeping process and increased at a lower magnitude during the germination, where its enzymatic activity peaked on the fourth day of germination. The best germination time is between four to five days regarding the enzymatic activities of xylanases in the wheat malt. During the drying process, both endo- $\beta-1,4$-xylanase and $\alpha$-Larabinofuranosidase in the wheat malt were not heatresistant whereas $\beta$-D-xylosidase was heat resistance. In the malting process, the conversion of WUAXs into WEAXs in the wheat by the endogenous endo- $\beta-1,4-$ xylanase was more intense during the steeping process and the first day of germination. Endo- $\beta-1,4$-xylanase was the main degrading enzyme in the degradation of AXs and the increase of the WEAXs content in the malting process.

\section{Acknowledgements}

The authors thank the National Natural Science Foundation of China (project 31301548).

\section{References}

1. Krstanović, K. Mastanjević, V. Nedović, K. Mastanjević, Ferment, 5, 89 (2019).

2. Rakszegi, A. Lovegrove, K. Balla, L. Láng, Z. Bedö, O. Veisz, P. R. Shewry, CARBOHYD POLYM, 102, 557-565 (2014).

3. L. Ravn , H. J. Martens, P. Dan, N. R. Pedersen, ANIM FEED SCI TECH, 219, 216-225 (2016).
4. Faltermaier, D. Waters, T. Becker, E. Arendt, M. Gastl, J I BREWING, 120, 1-15 (2014).

5. B. Revanappa, C. D. Nandini, P. V. Salimath, FOOD HYDROCOLLOID, 43, 736-742 (2015).

6. G. Mohamed, G. Ali, B. Hafedh, J MOL CATAL BENZYM, 68, 192-199 (2011).

7. M. Mendis, S. Simsek, CARBOHYD POLYM, 132, 452-459 (2015).

8. Y. J. Han, H. Z. Chen. J MOL CATAL B-ENZYM, 63, 135-140 (2010).

9. A. Egi, R. A. Speers, P. B. Schwarz, MBAA TQ, 41, 248-267 (2004).

10. M. Guo, K. Xu, Z. Wang, J I BREWING, 125, 288293 (2019).

11. M. Gupta, N. Abu-Ghannam, E. Gallagha, COMPR REV FOOD SCI F, 9, 318-328 (2010).

12. Z. J. Peng, Y. H. Jin, MOLECULES, 25 (2020).

13. M. S. Izydorczyk, J. E. Dexter, FOOD RES INT, 41, 850-868 (2008).

14. W. Debyser, G. Derdelinckx, J. A. Delcour, J CEREAL SCI, 26, 67-74 (1997).

15. J. Y.Han. FOOD CHEM, 70, 131-138 (2000).

16. P. B. Schwarz, J. Y. Han, J AM SOC BREW CHEM, 53, 157-159 (1995).

17. Y. H. Jin, J. H. Du, K. L. Zhang, L. Xie, P. P. Li, J I BREWING, 118, 57-62 (2012).

18. J. Lu, Y. Li, FOOD CHEM, 98, 164-170 (2006).

19. Y. H. Jin, K. L. Zhang, J. H. Du, J I BREWING, 114, 289-293 (2008).

20. X. Guo, Y. H. Jin, J. H. Du, J CEREAL SCI, 74, 218-223 (2017). 